\title{
The Relationships among Involvement Level, Service Failure, Service Recovery Disconfirmation and Customer Lifetime Value
}

\author{
M. C. Lai and F. S. Chou
}

\begin{abstract}
Because service failure can't be fully avoided in the process transmission, understanding the service failure severity and their impact on customer responses and designing effective recovery strategies have been recognized as important problems by both service researchers and practitioners. There is still a lack of research on the link between service disconfirmation and the value of a customer to the firm. Also the previous research on service recovery has not incorporated important contextual factors, such as the involvement level of individual differences and the perceived severity of service failure across customers, into analytical models or empirical testing. To address the aforementioned knowledge gaps. The research we would like to focus on building a disconfirmation theory, we would like to find out the affect from the gap between of disconfirmation and expectations of service recovery and perceived performance of service recovery to customer lifetime value in children English learning material/service. The empirical result demonstrates that service failure severity can enhance service recovery expectation in customers' mind. Analysis also indicates that both service recovery expectation and service recovery performance significantly affect service recovery disconfirmation. Last, service recovery disconfirmation also influences customer lifetime value significantly.
\end{abstract}

Index Terms-Involvement, service failure, children english learning material, service recovery disconfirmation, customer lifetime value.

\section{INTRODUCTION}

In today's globally competitive market, few companies can claim to offer a product so unique that the competitors fail to match it. As a result, service quality is the core component of the service promise. It represents an important aspect of overall values and is often a means used by consumers to judge a firm's performance. Firms that earn a reputation and market share [1] for superior customer service are more likely to get the competitive advantage in highly competing environment.

Because foreseeing that service failures are unavoidable, the quality of service recovery becomes the most important determinant of customer satisfaction and loyalty [2]. From the involvement level of individual differences, and the perceived severity of service failure across customers, managing service recovery disconfirmation is increasingly viewed as critical by most firms to achieve market

Manuscript received November 9, 2013; revised January 8, 2014.

M. C. Lai is with the Graduate Institute of Business Administration National Taipei College of Business, Taiwan (e-mail: laimc@mail.ntcb.edu.tw).

F. S. Chou was with the Department of Business Administration, National Taipei University, Taiwan (e-mail: choufengsha@gmail.com). differentiation and competitive advantage.

This paper, presents two perspectives, the involvement level of individual differences, and the perceived severity of service failure across customers on managing service failures. And from the disconfirmation theory, finding out the affect from the gap between disconfirmation, and expectations of service recovery and perceived performance of service recovery to customer lifetime value in children's English learning material/service. It is argued that adopting a customer perspective on service failure management is potentially more beneficial for service providers in the long term, because it can contribute to the customer lifetime value in the future and to the development of a customer value-based competitive advantage.

\section{LITERATURE REVIEW}

\section{A. Consumer Involvement}

Like most consumer researchers, the perceived personal relevance is viewed as the essential characteristic of involvement [3]-[5]. That is, a consumer's level of involvement with an object, situation, or action is determined by the degree to which he/she perceives that concept to be personally relevant [6].

In this paper, the consumer involvement includes two dimensions, product involvement and situational involvement. The product involvement is defined as a consumer perceives linkage between an individual's needs, goals, and values and their product/service knowledge represents the personal relevance of a product/service. The situational involvement refers to under the specific situation, the level of a consumer concerns about product/service. To the extent that product/service characteristics are associated with personal goals and values, the consumer will experience strong feelings of personal relevance or involvement with the product/service [7].

\section{B. Service Failure and Service Recovery}

A service failure is defined as service performance that falls below a customer's expectations [8]. Service failure severity refers to a customer's perceived intensity of a service failure. Reference [9] describe service recovery as a process for returning aggrieved customers to a state of satisfaction with the organization after a service or product has failed. Service recovery includes the actions and activities that the service provider adapts to "rectify, amend, and restore the loss experienced" by customers as result of service deficiencies [2], [10]. But the more severe the service failure, the greater the customer's perceived loss [11]. Previous 
research suggests that the severity of the service failure will be influential in the evaluation of a service provider after a service failure [11], [12]. Therefore, a severe service failure will affect the customer service recovery satisfaction negatively, even when a sufficient recovery has taken place [13].

\section{Service Recovery Disconfirmation}

Consumers would compare the perceived performance of a product/service against their prior expectations [14], [15]. Whether the comparison outcome could be perceived as worse than expected (a negative disconfirmation), better than expected (a positive disconfirmation) or just as expected (a zero disconfirmation or confirmation), will directly drive the satisfaction evaluation [16].

In service recovery, the disconfirmation still exists. It includes three items, service recovery satisfaction (SRS), service recovery expectation (SRE), and service recovery performance (SRP). Just like the Expectancy Disconfirmation Theory, a customer who suffered a service failure will also have an expectation for the service recovery from the service provider. If the evaluation of the service recovery is positive ( $\mathrm{SRE}<\mathrm{SRP}$ ), there will be a service recovery confirmation. In other words, when a customer feels the negative service recovery satisfaction, it will produce a service recovery disconfirmation (SRE $>$ SRP) [17]. The service recovery confirmation/disconfirmation also brings an overall attitude towards a product, service, or firm. This attitude a customer holds towards an object guides the behaviors such as repeat purchases, eventual brand loyalty and word-of-mouth.

\section{Customer Lifetime Value}

Profitable customer refers to the customers that can raise income constantly for the company, and the income could remedy the level above the cost of the company. In fiercely competitive environments, different marketing strategies should be aimed at different customer groups. Customer lifetime value (CLV) is an important factor that effects the distributing of promotions, allocating of resources, and other decisions for retaining customers in a company.

Reference [18] defined CLV as the present value of profit from a customer within a certain period. On the other hand, Reference [19] from comprehensive view claimed that CLV can be divided into two types: (1) Core Relation: including "Usages Factor" and "Fan Identification". (2) Extend relation: including "Product Merchandising" and "Word of Mouth". Our study summarized financial and marketing view, and increased the research variable of CLV, as in [18], [19].

TABLE I: MEASUREMENT VARIABLES OF CUSTOMER LIFETIME VALUE

\begin{tabular}{ll}
\hline \hline \multicolumn{1}{c}{ Category } & \multicolumn{1}{c}{ Definition } \\
\hline Usage Factor & $\begin{array}{l}\text { It means the length and depth of the relationship } \\
\text { between the company and customer, or the } \\
\text { frequency that customers contact with the } \\
\text { company. }\end{array}$ \\
\hline Fan Identification & $\begin{array}{l}\text { It means customer's deeply held commitment and } \\
\text { the involved degree of emotion. }\end{array}$ \\
\hline Product Merchandising & $\begin{array}{l}\text { Through the marketing elements to affect the } \\
\text { degree of purchasing tendency. }\end{array}$ \\
\hline Word of Mouth & $\begin{array}{l}\text { Present customers recommend the products or } \\
\text { service to others. }\end{array}$ \\
\hline Opportunity Cost & $\begin{array}{l}\text { When compare with other choices, the satisfaction } \\
\text { degree of customer spent time or money. }\end{array}$ \\
\hline \hline Source: A. M. Hughes, (1994): 91, M. McDonald, (1996): 18.
\end{tabular}

We quote five variables to weighing CLV to probe this theme: Usage factor, fan identification, product merchandising, word of mouth, and opportunity cost, shown as Table I.

\section{ConcePtual DeVelopment AND Hypotheses}

\section{A. Conceptual Framework}

Fig. 1 presents our conceptual framework. As shown, we propose that the level of consumer involvement affects SRE, and the severity of service failure affects both of SRE and SRP. Next, the conceptual model proposes that both the SRE and SRP affect the service recovery disconfirmation. Finally, the service recovery disconfirmation is expected to influence CLV. In the following sections, we define several key constructs and then present specific hypotheses regarding the relationships shown in Fig. 1.

\section{B. Hypotheses}

\section{1) Consumer involvement and SRE}

When the purchasing behavior might lead to the uncertain or unhappy result, the behavior is risky. The more risk the consumer perceives, the higher the level of consumer involvement [6]. Under high involvement, the frequency and quantity of consumer collecting information increased incredibly. Reference [20] mention that consumers with higher involvement know more about the differences and importance among products, and have a higher commitment to the brand. Reference [21] point out that situational factors influence the relative effectiveness of the recovery strategies. It means that the different importance of events in customers' mind is related to the response from customers.

So the consumers with high involvement usually realize more about their real needs, and the benefit they can get from the service. Therefore, compared to the consumers with lower involvement, the consumers with higher involvement would expect the firm to provide the reasonable and satisfying service recovery when they experienced a service failure. Based on the preceding discussion, the following hypothesis is offered:

H1: The level of consumer involvement will have a positive relationship to SRE.

\section{2) Service failure, $S R E$, and $S R P$}

Service failure severity refers to a customer's perceived intensity of a service problem. The more intense or severe the service failure, the greater the customer's perceived loss. Previous research suggests that the severity of the service failure is influential in the evaluation of a service provider after a service failure [22].

Reference [23] suggest that customers' zones of tolerance for service varies like an accordion's movement depending on the situation. They maintain that a service failure is one of the major factors that narrow the customers' zone of tolerance. In the case of a service failure, customers' expectations may increase, resulting in a narrower zone of tolerance than that of first-time service encounter. As the service problem becomes more severe, the customers' tolerance zone gets narrower, thus increasing the potential for customer dissatisfaction [24]. Therefore, we expect that the severity of the service failure has a positive influence on SRE, 
and a negative influence on SRP. Based on the previous discussion, the following hypotheses are offered:

$\mathrm{H} 2$ : The severity of service failure will have a positive relationship to SRE.

H3: The severity of service failure will have a negative influence on SRP.

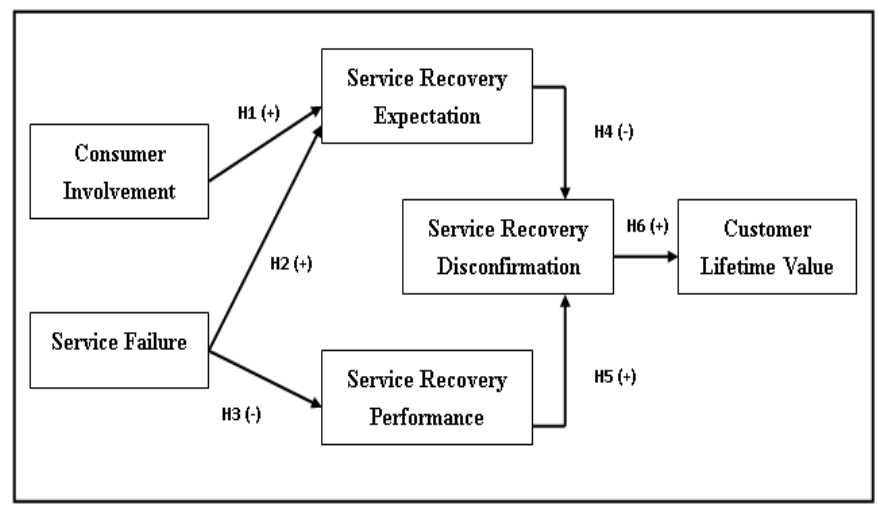

Fig. 1. Conceptual model.

\section{3) SRE, SRP, and service recovery disconfirmation}

A service failure represents a firm's shortfall in maintaining service reliability. But service recovery is also an opportunity to reverse the process. Customers can be quite forgiving when a service fails [25], and are usually willing to provide the business with an opportunity to rectify its mistakes [8]. According to the research as in [26], "Every customer problem is an opportunity for the company to prove its commitment to service - even if the company is not to blame".

The key determinant whether the customer feels satisfied or not after service failure depends on the gap, the service recovery disconfirmation between the SRP of service providers and the SRE of customers. Thus, customers' SRE serve as a reference point that determines whether customers frame a specific recovery as a gain ( $\mathrm{SRP}>\mathrm{SRE}$ ) or a loss $(\mathrm{SRP}<\mathrm{SRE})$. So, if the firm could provide more excellent and adequate SRP, it will be easier to match or exceed the customers' SRE. In contrast, the higher the customers' SRE, the harder the positive service recovery disconfirmation. Based on the preceding discussion, the following hypotheses are offered:

H4: SRE will have a negative relationship to the service recovery disconfirmation.

H5: SRP will have a positive relationship to the service recovery disconfirmation.

\section{4) Service recovery disconfirmation and $C L V$}

Reference [27] suggest that the customers' favorable behavior is usually to commend the company to others, to applaud the company's advantage, to increase usage from the company, or willing to pay for the company's coupon. In contrast, unfavorable behavior is about quitting, and decreasing the usage.

Previous research supports the relationship among satisfaction, trust [28], and commitment [29]. Research on service recovery also mentions the relationship among satisfaction, trust, and commitment [30], [31]. Researchers have observed that good service recovery strategies are important elements for increasing satisfaction and building long-term customer relationships [26].

Therefore, companies should make an effort to achieve the positive service recovery disconfirmation. In doing so it will, raise customers' usage, promote a positive image, encourage customer loyalty and even positive word-of-mouth advertising. From this foundation, companies could also build up the opportunity cost concept in customers' mind easily, and get competition advantage in the highly competing environment. Based on the preceding discussion, the following hypotheses are offered:

H6: Service recovery disconfirmation will have a positive relationship to CLV.

H6-1: Service recovery disconfirmation will have a positive relationship to usage factor.

H6-2: Service recovery disconfirmation will have a positive relationship to fan identification.

H6-3: Service recovery disconfirmation will have a positive relationship to product merchandising.

H6-4: Service recovery disconfirmation will have a positive relationship to word-of-mouth.

H6-5: Service recovery disconfirmation will have a positive relationship to opportunity cost.

\section{SAmple And Measurement}

Data was collected using face-to-face and mail questionnaire to the members of a children's English learning material/service company in Taiwan. After purchasing children English learning material, customers have to pay a monthly fee in order to make use of the services (repaired/renewed the material, use the web site, join the activities, etc.). A total of 102 did not complete or answer the surveys and were excluded from further analysis, resulting in 123 usable responses, for an effective response rate of $54.7 \%$. In terms of demographic characteristics of the sample, most live in the northern section of Taiwan (78.9\%). The majority of respondent is female (86.2\%), 31-40 years of age (73.0\%), college/university education $(74.0 \%)$, and average $\$ 60,001-80,000$ household income per month (27.9\%). Most of them had been members for less than one year (26.4\%).

Consumer Involvement: Consumer involvement taps as in[32].A five point Liker-type scale was used for recording the responses ( $1=$ strongly disagree; $5=$ strongly agree $)$. Exploratory factor analysis (EFA) was used. Principal component analysis with varimax rotation extracted three factors, specified based on eigenvalues of one or more with the screed test. These three factors combine to explain $65.41 \%$ of the variance in the data. Factor loadings range from 0.609 to 0.869 . It includes three sub-dimensions to measure consumer involvement: Epicureanism purchasing, self perceived and negative conservatism.

Service Failure: Because of the lack of empirical investigation of service failure for children English learning material/service, the measure is derived from the outcome of discussing with the employees in customer service center and department of members' services. This scale measure three sub-dimensions of the service failure construct: service attitude failure, service delivery system failure, and material/service effectiveness failure. To assess the service failure severity, a five point Liker-type scale was used (1= strongly disagree; 5= strongly agree). EFA was used. 
Principal component analysis with varimax rotation extracted three factors, specified based on eigenvalues of one or more with the screed test. These three factors combine to explain $67.23 \%$ of the variance in the data. Factor loadings range from 0.587 to 0.870 .

SRE, SRP, and Service Recovery Disconfirmation: The SRE, SRP, and service recovery disconfirmation scale were adopted from researcher's RECOVSAT, as in [17]. To assess SRE and SRP, a ten point Liker-type scale was used ( $1=$ very unimportant/ very dissatisfied; $10=$ very important/ very satisfied). And the service recovery disconfirmation equals SRE minus SRP. If the outcome is positive (SRE>SRP), it will be a negative disconfirmation. In other words, the disconfirmation will be positive, when the score of SRE is lower than SRP. Confirmatory factor analysis (CFA) was used. This scale measure six sub-dimensions of the SRE, SRP, and service recovery disconfirmation construct: communication, empowerment, feedback, atonement, explanation, and tangibles.

CLV: This study combined financial and marketing perspectives to measure CLV. Reference [18],[19] research variables were both conducted. To assess CLV, a five point Liker-type scale was used ( $1=$ strongly disagree; $5=$ strongly agree). CFA was also used. This scale was designed to measure six sub-dimensions of the CLV construct: usage factor, fan identification, product merchandising, word-of-mouth, and opportunity cost.

Cronbach's $\alpha$ coefficient is used to verify internal validity. Reference [33] indicates that the measurement will have high validity if the coefficient is greater than 0.7 . Reference [34] also points out that the value of $0.7-0.98$ indicates a high validity, $0.35-0.7$ is acceptable, and lower than 0.35 should be rejected. Most of the reliabilities of the consumer involvement, service failure, RECOVSAT, and CLV scales exceed 0.7 , except the negative conservative factor of consumer involvement $(0.675)$, the service delivery system failure factor of service failure (0.644), and SRE - tangibles factor of RECOVSAT (0.683). All constructs and reliability values of each scale are shown in Table II- Table IV.

TABLE II: THE EFA OF CONSUMER INVOLVEMENT

\begin{tabular}{cccc}
\hline \hline Items & Factor 1 & Factor 2 & Factor 3 \\
\hline 2 & 0.866 & & \\
1 & 0.861 & & \\
3 & 0.804 & & \\
4 & 0.609 & & \\
10 & & 0.852 & \\
5 & & 0.816 & \\
9 & & 0.680 & \\
8 & & & 0.869 \\
7 & & & 0.823 \\
6 & 2.601 & 2.102 & 0.615 \\
\hline Eigenvalues & 26.011 & 47.030 & 65.405 \\
Cumulative \% & 0.806 & 0.729 & 0.675 \\
Cronbach $\alpha$ & Epicureanism & Self & Negative \\
\hline The Factor's Name & Purchasing & Perceived & Conservatism \\
\hline \hline
\end{tabular}

\section{ANALYSIS AND RESUlT}

The research hypotheses were tested using the multiple regression models. Table $\mathrm{V}$ shows the analytical results. It illustrates that service failure severity significantly affects SRE $(F=13.022, \mathrm{p}<0.001)$. On the other hand, SRE and SRP both influence service recovery disconfirmation $(F=62.582$, $p<0.001 ; \quad F=125.409, \quad p<0.001)$. Service recovery disconfirmation also has a significant, positive relationship with $\operatorname{CLV}(F=3.340, p<0.1)$.

TABLE III: THE EFA OF SERVICE FAILURE

\begin{tabular}{cccc}
\hline \hline Items & Factor 1 & Factor 2 & Factor 3 \\
\hline 9 & 0.870 & & \\
6 & 0.862 & & \\
12 & 0.853 & & \\
14 & 0.826 & & \\
13 & 0.811 & & \\
7 & 0.784 & & \\
8 & 0.657 & & \\
5 & 0.587 & 0.692 & \\
3 & & 0.688 & \\
2 & & 0.611 & 0.789 \\
1 & & 0.599 & 0.693 \\
4 & & & 1.784 \\
10 & & 2.145 & 0.793 \\
11 & 5.484 & 54.491 & \\
\hline Eigenvalues & 39.172 & 0.644 & \\
Cumulative \% & 0.931 & Service & Material/Service \\
Cronbach $\alpha$ & Service & Delivery & Effectiveness Failure \\
\hline The Factor's & Attitude & System Failure & \\
Name & Failure & & \\
\hline \hline
\end{tabular}

\begin{tabular}{|c|c|c|c|}
\hline Construct and factors & $\begin{array}{l}\text { No. of } \\
\text { Items }\end{array}$ & Cumulative \% & Cronbach $\alpha$ \\
\hline \multicolumn{4}{|c|}{ Service Recovery Expectation } \\
\hline Communication & 5 & 88.631 & 0.967 \\
\hline Empowerment & 3 & 76.515 & 0.846 \\
\hline Feedback & 2 & 87.097 & 0.849 \\
\hline Atonement & 3 & 74.610 & 0.825 \\
\hline Explanation & 2 & 91.116 & 0.897 \\
\hline Tangibles & 2 & 76.022 & 0.683 \\
\hline \multicolumn{4}{|c|}{ A. Service Recovery Performance } \\
\hline Communication & 5 & 81.172 & 0.941 \\
\hline Empowerment & 3 & 74.495 & 0.822 \\
\hline Feedback & 2 & 93.410 & 0.929 \\
\hline Atonement & 3 & 81.350 & 0.881 \\
\hline Explanation & 2 & 93.024 & 0.924 \\
\hline Tangibles & 2 & 78.992 & 0.734 \\
\hline \multicolumn{4}{|c|}{ B. Customer Lifetime Value } \\
\hline Usage Factor & 3 & 76.795 & 0.844 \\
\hline Fan Identification & 3 & 68.659 & 0.772 \\
\hline Product Merchandising & 3 & 63.497 & 0.705 \\
\hline Word-of-Mouth & 2 & 87.099 & 0.851 \\
\hline Opportunity Cost & 3 & 72.039 & 0.790 \\
\hline
\end{tabular}

TABLE V: THE ANALYTICAL RESULTS

\begin{tabular}{|c|c|c|c|c|c|c|c|c|}
\hline & \multicolumn{2}{|c|}{$\begin{array}{c}\text { Service } \\
\text { Recovery } \\
\text { Expectation }\end{array}$} & \multicolumn{2}{|c|}{$\begin{array}{c}\text { Service } \\
\text { Recovery } \\
\text { Performance }\end{array}$} & \multicolumn{2}{|c|}{$\begin{array}{c}\text { Service } \\
\text { Recovery } \\
\text { Disconfirmat } \\
\text {-ion }\end{array}$} & \multicolumn{2}{|c|}{$\begin{array}{l}\text { Customer } \\
\text { Lifetime } \\
\text { Value }\end{array}$} \\
\hline & $\begin{array}{c}\mathrm{F} \\
\text { value }\end{array}$ & $\begin{array}{c}\mathrm{p} \\
\text { value }\end{array}$ & $\begin{array}{c}\mathrm{F} \\
\text { value }\end{array}$ & $\begin{array}{c}\mathrm{p} \\
\text { value }\end{array}$ & $\begin{array}{c}\mathrm{F} \\
\text { value }\end{array}$ & $\begin{array}{c}\mathrm{p} \\
\text { value }\end{array}$ & $\begin{array}{c}\mathrm{F} \\
\text { value }\end{array}$ & $\begin{array}{c}\mathrm{p} \\
\text { value }\end{array}$ \\
\hline $\begin{array}{c}\text { Consumer } \\
\text { Involvement }\end{array}$ & 1.86 & 0.18 & - & - & - & - & - & - \\
\hline Service Failure & 13.02 & 0.00 & 0.40 & 0.53 & - & - & - & - \\
\hline $\begin{array}{l}\text { Service Recovery } \\
\text { Expectation }\end{array}$ & - & - & - & - & 62.58 & 0.00 & - & - \\
\hline $\begin{array}{l}\text { Service Recovery } \\
\text { Performance }\end{array}$ & - & - & - & - & 125.41 & 0.00 & - & - \\
\hline $\begin{array}{l}\text { Service Recovery } \\
\text { Disconfirmation }\end{array}$ & - & - & - & - & - & - & 3.34 & 0.07 \\
\hline
\end{tabular}

From above, H2, H4, H5, and H6 are supported. And H1 and $\mathrm{H} 3$ are not. We also tested the relationship between 
service recovery disconfirmation and five dimensions of CLV. The results are listed in Table VI. Service recovery disconfirmation only significantly affects opportunity cost $(F=3.340, p<0.05)$. Totally, only H6-5 is supported, others are not. All supported hypotheses are shown in Fig. 2.

TABLE VI: THE ANALYTICAL RESULTS IN CLV

\begin{tabular}{|c|c|c|c|c|c|c|c|c|c|c|}
\hline & \multicolumn{10}{|c|}{ "Customer Lifetime Value } \\
\hline & $\begin{array}{l}\text { Usa } \\
\text { Fact }\end{array}$ & $\begin{array}{l}\text { ge } \\
\text { tor }\end{array}$ & $\begin{array}{r}\mathrm{Fa} \\
\text { Identifi }\end{array}$ & $\begin{array}{l}\text { n } \\
\text { cation }\end{array}$ & $\begin{array}{r}\text { Proc } \\
\text { Merch } \\
- \text { ir } \\
\end{array}$ & $\begin{array}{l}\text { duct } \\
\text { handis } \\
\text { ng }\end{array}$ & $\begin{array}{l}\text { Wor } \\
\text { Mo }\end{array}$ & $\begin{array}{l}\text { rd of } \\
\text { onth }\end{array}$ & Oppor & $\begin{array}{l}\text { rtunity } \\
\text { lost }\end{array}$ \\
\hline & $\begin{array}{c}\mathrm{F} \\
\text { value }\end{array}$ & $\begin{array}{c}\mathrm{p} \\
\text { value }\end{array}$ & $\begin{array}{c}\mathrm{F} \\
\text { value }\end{array}$ & $\begin{array}{c}\mathrm{p} \\
\text { value }\end{array}$ & $\begin{array}{c}\mathrm{F} \\
\text { value }\end{array}$ & $\begin{array}{c}\mathrm{p} \\
\text { value }\end{array}$ & $\begin{array}{c}\mathrm{F} \\
\text { value }\end{array}$ & $\begin{array}{c}\mathrm{p} \\
\text { value }\end{array}$ & $\begin{array}{c}\mathrm{F} \\
\text { value }\end{array}$ & $\begin{array}{c}\mathrm{p} \\
\text { value }\end{array}$ \\
\hline $\begin{array}{c}\text { Service } \\
\text { Recovery } \\
\text { Disconfir- } \\
\text { mation }\end{array}$ & 0.60 & 0.44 & 0.82 & 0.37 & 1.35 & 0.25 & 0.95 & 0.33 & 9.69 & 0.00 \\
\hline
\end{tabular}



$\mathrm{p}<0.01 * * *, \mathrm{p}<0.05 * *, \mathrm{p}<0.1 *$

Fig. 2. Results of the multiple regression model.

\section{DISCUSSION}

\section{A. Conclusion and Implication}

The findings of this study demonstrate that service failure severity can enhance SRE in customers' mind. Both SRE and SRP also influence service disconfirmation recovery significantly. So service provider should adopt different service recovery strategies depending upon the severity of the problem. They also have to first develop a system for tracking and identifying service failures and their level of severity. Firms should avoid solving customer complain by standard, low cost methods. Customer contact employees should be trained to recognize the varying severity of service failures from the customers' perspective and to treat customers possessing varying degrees of negative emotions. Because they are the only one person who can fully express customers' thoughts to service manager. From this source, service manager could understand more about customers' real recovery expectation, and response that by the best recovery performance in the shortest time to promote the positive disconfirmation.

On the other hands, although service recovery disconfirmation has a positive relationship with CLV, but it significantly affects the only one dimension, opportunity cost. It might be because that the price of children's learning English material is so expensive that it has built up the higher transfer cost imperceptibly. Sometimes, despite parents are not satisfied the firm's service, but children enjoy the English material so much. It leads to the result that the parents are too hard to change to other brand. Therefore, service provider should use the high opportunity cost as a foundation to develop the long-term, positive relationship in usage factor, fan identification, product merchandising, and word of mouth. Firm can have more activities to contact with children, like birthday card, Christmas present, interactive English on line games, and children English weekly news, etc. For parents, more material/service coupon, exchanging using experience with other members, and providing use consulting actively, etc. is the best linkage with positive CLV.

\section{B. Limitations and Future Research}

The implications from this study must be tempered by its limitations. First, since the study used a confined research context to investigate, care should be taken when extending the conclusions of the study to other contexts. Whereas the findings were consistent across one industry, the context still limits its generalizability. Therefore, it is important that future research attempts to replicate the findings in other service industries. Research is also needed to test the results in different areas such as industrial sales and business-to-business services marketing. The number of samples in this study might be too less to cover all customers' problem. Future research could collect more samples to representative the real context.

Because understanding the black box in customers' mind is so important. Training a professional employee standing on the first line is also a key factor to decide whether firms could touch customers' real needs, even after service failures. How to develop a professional employee? What characteristics should a customer contact employee have? Are there any relationships between service recovery disconfirmation and customer contact employees? Hopefully additional research into the service topics will lead to a better understanding of service failures and service recovery.

\section{REFERENCES}

[1] C. A. de Matos, D. V. der H. Fernandes, R. P. Leis, and G. Trez, "A cross-cultural investigation of customer reactions to service failure and recovery," Journal of International Consumer Marketing, vol. 23, pp. 211-228, 2011.

[2] T. F. J. Steyn, P. G. Mostert, C. F. De Meyer, and L. R. J. van Rensburg, "The effect of service failure and recovery on airline-passenger relationships: A comparison between south African and united states airline passengers," Journal of Management Policy and Practice, vol. 12, no. 5, pp. 105-115, 2011.

[3] M. L. Richins and P. H. Bloch, "After the new wears off: The temporal context of product involvement," Journal of Consumer Research, vol. 13, pp. 280-235, September 1986.

[4] J. L. Zaichkowsky, "Measuring the involvement construct," Journal of Consumer Research, vol. 12, pp. 341-352, December 1985.

[5] R. E. Petty and J. T. Cacioppo, "Issue involvement as a moderator of the effects on attitude of advertising content and context," in NA Advances in Consumer Research, MI: Association for consumer research, vol. 8, pp. 20-24, 1981.

[6] G. Sridhar, "Consumer involvement in product choice: Role of perceived risk," Decision, vol. 34, no. 2, pp. 51-66, 2007.

[7] M. F. Guthrie and H. S. Kim, "The relationship between consumer involvement and brand perceptions of female cosmetic consumers," Journal of Brand Management, vol. 17, pp. 114-133, 2009.

[8] K. D. Hoffman and J. E. G. Bateson, Essentials of Services Marketing, Fort Worth, TX: Dryden, 1997.

[9] R. Zemke and C. Bell, "Service recovery: Doing it right the second time," Training, vol. 27, no. 6, pp. 42-48, 1990.

[10] C. Gronroos, "Service quality: The six criteria of good perceived service quality," Review of Business, vol. 9, pp. 10-13, winter 1988.

[11] S. C. Chuang, Y. H. Cheng, C. J. Chang, and S. W. Yang, "The effect of service failure types and service recovery on customer satisfaction: a mental accounting perspective," The Service Industries Journal, vol. 32 , no. 2, pp. 257-271, 2012. 
[12] A. K. Smith, R. Bolton, and J. Wagner, "A model of customer satisfaction with service encounters involving failure and recovery," Journal of Marketing Research, vol. 36, pp. 356-372, August 1999.

[13] H. Liao, "Do it right this time: The role of employee service recovery performance in customer-perceived justice and customer loyalty after service failures," Journal of Applied Psychology, vol. 92, no. 2, pp. 475-489, 2007

[14] D. K. Tse, M. N. Franco, and P. C. Wilton, "Consumer satisfaction as a process," Psychology and Marketing, vol. 7, no. 3, pp. 177-193, 1990.

[15] R. T. Rust and R. L. Oliver, "Service quality: Insights and managerial implications from the frontier," in Service Quality: New Directions in Theory and Practice, R. T. Rust and R. L. Oliver, Sage, 1994, pp. 1-19.

[16] R. L. Oliver, "Measurement and evaluation of satisfaction processes on retail settings," Journal of Retailing, vol. 57, no. 3, pp. 25-48, 1981.

[17] C. Boshoff, "RECOVSAT: An instrument to measure satisfaction with transaction-specific service recovery," Journal of Service Research, vol. 1, no. 3, pp. 236-249, 1999.

[18] A. M. Hughes, Strategic Database Marketing, Chicago, IL: Probus Publishing Company, 1994.

[19] M. Donald, "Service quality and customer lifetime value in professional sport franchises," Electronic D. dissertation, Massachusetts Univ., U. S., 1996.

[20] J. L. Lastovicka and D. M. Gardner, "Low involvement versus high involvement cognitive structures," Advances in Consumer Research, vol. 5, pp. 87-92, 1978.

[21] C. Webster and D. S. Sundaram, "Service consumption criticality in failure recovery," Journal of Business Research, vol. 41, no.2, pp. 53-159, 1998.

[22] C. A. de Matos, V. A. Vieira, and R. T. Veiga, "Behavioural responses to service encounter involving failure and recovery: the influence of contextual factors," Service Industries Journal, vol. 32, no. 14, pp. 2203-2217, 2012.

[23] V. A. Zeithaml, L. L. Berry, and A. Parasuraman, "The nature and determinants of customer expectations of service," Journal of the Academy of Marketing Science, vol. 21, no. 1, pp. 1-12, 1993.

[24] K. D. Hoffman, S. W. Kelley, and H. M. Rotalsky, "Tracking service failures and employee recovery efforts," Journal of Services Marketing, vol. 9 , no. 2, pp. 49-61, 1995.

[25] R. Mack, R. Mueller, J. Crotts, and A. Broderick, "Perceptions, corrections and defections: Implications for service recovery in the restaurant industry," Managing Service Quality, vol. 10, no. 6, pp. 339-346, 2000

[26] C. Hart, J. Heskett, and W. E. Sasser, "The profitable art of service recovery," Harvard Business Review, vol. 68, no.4, pp. 148-156, 1990.
[27] V. A. Zeithaml, L. L. Berry, and A. Parasuraman, "The behavioral consequences of service quality," Journal of Marketing, vol. 60, pp. 31-46, 1996.

[28] S. Ganesan, "Determinants of long-term orientation in buyer-seller relationships," Journal of Marketing, vol. 58, no. 2, pp. 1-19, 1994.

[29] S. W. Kelley and M. A. Davis, "Antecedents to customer expectations for service recovery," Journal of the Academy of Marketing Science, vol. 22 , no. 1, pp. 52-61, 1994.

[30] S. La and B. Choi, "The role of customer affection and trust in loyalty rebuilding after service failure and recovery," The Service Industries Journal, vol. 32, no. 1, pp. 105-125, 2012.

[31] S. S. Tax, S. W. Brown, and M. Chandrashekaran, "Customer evaluations of service complaint experiences: Implications for relationship marketing," Journal of Marketing, vol. 62, no. 2, pp. 60-76, 1998.

[32] S. T. Huang, "A study on the relationships among product involvement, brand equity, emotional advertising appeals and purchase intentiontaking the cellular phone as example," M. S. thesis, Da-Yeh Univ. Changhua, Taiwan, 2004.

[33] J. C. Nunnally, Psychometric Theory, $2^{\text {nd }}$, NY: McGraw-Hill, 1978.

[34] R. Wortzet, "New life style determinants of women's food shopping behavior," Journal of Marketing, vol. 43, pp. 28-39, 1979.



Ming-Cheng Lai is an associate professor and the dean of the Graduate Institute of Business Administration at National Taipei College of Business in Taiwan. The focus of his research is on competitive strategy, marketing strategy, and brand strategy. $\mathrm{He}$ has published extensively, and his articles have appeared in various journals, including international journal of innovation, management and technology, knowledge-based system, Taiwan journal of marketing science, international journal of innovative computing, information and control, and Chinese business review.

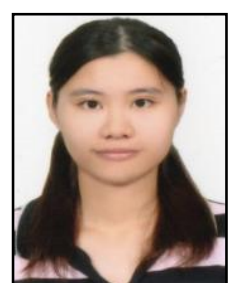

Feng-Sha Chou is a Ph.D. student at the Graduate Institute of Business Administration at National Taipei University in Taiwan. The focus of her research is on marketing strategy and brand strategy. She has published extensively, and her articles have appeared in various journals, including Taiwan journal of marketing science and Chinese business review. 